Roscoe and W. J. Russell, on " Experiments suitable for Illustrating Elementary Instruction in Chemistry." These notes appear to me to be very usefiul as a rough guide to the schoolteacher. But unless the teacher is able to arrange the experimental illustrations so that some conclusions regarding the elementary principles of chemistry shall be drawn from the results he obtains, which conclusions shall then be subuitted to experimental examination, I think the notes will fail of their object.

It is to the want of progressiveness in the ordinary chemical course that I wish to draw attention.

The student of physics advances; he feels his way from one set of phenomena to another ; he generalises, and gets hold of some principles on which he may rest. In the ordinary chemical course the student begins with enthusiasm; he is delighted with the experiments, and he takes a lively interest in the manipulative failures of the lecturer. But, after a little, the student finds that he is not progressing. When he has been told, and shown, the properties of hydrogen, oxygen, and water, he is expected to take as much intercst as cver in hearing a list of properties of nitrogen and oxides of nitrogen. Then he fills his note-book with many facts regarding ammonia and nitric acid, and so on.

Now I do firmly belicve that chemistry is a branch of science, and that it may bc taught as such. I think it is possible, in a course of lectures on chcmistry, to lead the fairly intelligent and not very idle sturlent from simple facts about everydlay occurrences to the difficult and apparently remote discussions regarding the architecture of molecules, in which chemists so much delight.

If lcetures on chemistry werc arranged so that principles should be discussed and amply illustrated by well-chosen experiments, instead of being (as I am afraid is still too often the case) repetitions of disconnected facts about a string of elcments and compounds, I believe this branch of science would rapidly develop in this country. It seems to me that the distinction implied in the commonly-used terms chemistry and chemical philosophy is radically unsound. There are not two chemistrys, but one chemistry. Wc do not speak of physics as different from natural philosophy.

What we want is to convince our students that they are dealing. with rcalities. I am continually prescnted with answers to questions, which perhaps demand a knowledge of the laws of chemical combination, wherein a few clcmentary facts are elevated to the rank of an all-embracing theory, and complex structural formula are dealt with in a style of appalling familiarity, as if they were the topies which it is necessary to discuss on the very threshold of chemistry. One is told that chlorine is a monad, that is, it is a "one-armed one"; and then the conclusion is triumphantly announced, "thus wee see why it is" that hydrogen and chlorine combine to form hydrochloric acid, and so on. The other day I implored a candidate in a certain cxamination to give me a reason for writing the formula of alcohol $\mathrm{C}_{2} \mathrm{H}_{5} \ldots \mathrm{OH}$ rather than $\mathrm{C}_{2} \mathrm{H}_{6} \mathrm{O}$; he told me he had seen the former in a book. 'This is enough for the average student; and yet these people call themselves students of science. I am afraid the teachers are greatly to blame.

The examiners have undoubtedly much power; but I think the examinations in chemistry arc improving as a whole.

When a lecturer in chemistry announces two series of lectures, one elementary and one advanced, is it not very ofien found that the aclvancesl class is condemned to hear copious details regarding the purification and methods of separation of the rare metals, while the elementary class is entertained with an exhibition of the properties and reactions of the simple and compound gases? But is this chemistry?

I think that the teachers of chemistry must consent to abandon the time-honoured practice of placidly proceeding from element to element, and from compound to compound; they must ask themsclves whether they know of any reasons why chemistry should be called a branch of natural science, and, having conscientiously answered this question, they must try to make their students really aequainted with these reasons.

Dr. Sydiney Young (NATURE, vol, xxxi, p. I26) has referred to the paucity of good elementary text-books of chemistry. I, too, have felt the want of a really good book in attempting to teach the principles of chemistry to beginners. Is there any elementary book which treats chemistry as a gentine living science?

Cambridge, January 12

\section{A Method of Isolating Blue Rays for Optical Work}

IN many optical experiments, e.g. in examining the dispersion of optic axes in crystals, a homogreneous or monochromatic light is required. A fairly homogeneous rell light, nearly corresponding to the Fraunhofer line $\mathrm{B}$, can be ohtained by a properlyselceted piece of red glass placed in front of a good Argand burner or paraffin lamp. For yellow light, nothing can be better than the flame of a Bunsen's burner in which a bead of sodium carbonate is held in a loop of platinum wire. For blue rays, the light transmitted by a solution of cuprammonium sulphate is generally recommended, since the ordinary blue glass coloured with cobalt invariably transmits red rays as well as blue. Biut the use of a glass cell containing a strong ammoniacal solution is often inconvenient and unpleasant.

I have met with a peculiar kind of greenish-blue glass, user for railway signal lamps, and known as "signal-green glass" (coloured, I believe, with copper in its divalent condition), which is remarkably opaque to the less refrangible rays nearly as far as Fraunhofer's line $\mathrm{E}$, while it transmits a large quantity of blue and some green light. By combining a piece of this glass with a piece of rather deep-tinted cobalt glass, the red rays transmitted by the latter may be wholly stopped, and only the part of the

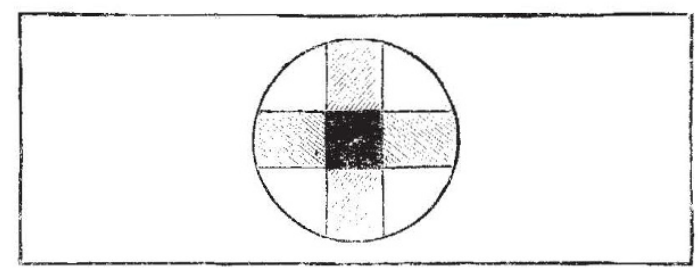

spectrum between $\mathrm{F}$ and $\mathrm{G}$ is transmitted, constituting a light at any rate not less homogeneous than that transmitted by solution of cuprammonium sulphate.

This "signal-green glass" is also useful in illustrating sclective absorption of light by different media. If, for instance, a picce of it is superposed on a piece of properly-sclccted red glass, each absorbs what the other transmits, and practically no luminous rays survive the two; only a faint neutral-tinted light struggling through, even when strong sunlight is used.

This can be well shown on the screen by fixing a narrow: strip of the "signal-green glass" vertically in a lantern-slide, and crossing it with a similar strip of red glass fixed horizontally in the same frame. The square space where the two overlap appears absolutely black.

The same arrangement is useful for other absorption-experiments, since the original colours of the media are shown, as well as the result of their superposition.

It is necessary to remember that much lighter tints are wanted for lantern-work than for subjective experiments.

Eton College, January to

H. G. MADAN

\section{Barrenness of the Pampas}

IN the admirable address of Prof. Asa Gray at Montreal, he alludes to the singular absence of trees and herbaceous plants throughout the Pampas or vast level plains of the South American continent, and he indorses the opinion of Mr. Darwin and Mr. Ball that this absence is due to the fact that the only country from which they could have been derived could not supply species adapted to the soil and climate. As this is a subject to which I paid considerable attention during a long residence in South America, I venturc to call attention to the explanation of this phenomenon, which my observations gave rise to as described in my "Visit to South America," 1878.

The peculiar characteristics of these vast level plains which descend from the Andes to the great river basin in unbroken monotony, are the absence of rivers or water-storage, and the pcriodical occurrence of droughts, or "siccos," in the summer months. Thesc conditions detcrmine the singular character both of its flora and fauna.

The soil is naturally fertile and favourable for the growth of trees, and they grow luxuriantly wherever they are protcctcr. The Eucalyptus is covering large tracts whercver it is inclosed, and willows, poplars, and the fig, surround every estancia when fenced in.

The open plains are covered with droves of horses and cattle, and overrun by numberless wild rodents, the original tenants of 